\title{
FUNGSI HUKUM DALAM PERUMUSAN ANGGARAN PENDAPATAN DAN BELANJA DESA MELALUI BADAN PERMUSYAWARATAN DESA
}

\author{
Endang Sutrisno, Ibnu Artadi, Khafdilah, Hesti Widianti \\ Universitas Swadaya Gunung Jati \\ Email : endangsutrisno94@gmail.com, ibnuartadi20@gmail.com, \\ khafdilah@gmail.com, widiantihesti5@gmail.com
}

\begin{abstract}
Village Consultative Agency (BPD - Badan Permusyawarat Desa) in implementing its function as a bridge connecting the village head with the village community must also carry out its main function as the representative. The problem arises is how does the legal order set issue of the Village Consultative Agency (BPD) on the perspective of the formulation of Village Revenues and Expenditures Budget (APBDes - Anggaran Pendapatan dan Belanja Desa) based on the legal basis of Government Regulation No. 72 of 2005 concerning the village. The next problem arises is what are the obstacles faced by the Village Consultative Agency (BPD) in carrying out its duties to prepare the Village Revenues and Expenditures Budget (APBDes). The process of formulating the Village Regulation has been carried out through the correct stages and in accordance with Law Number 6 of 2014 Jo Government Regulation Number 43 of 2014 concerning Jo Village Domestic Ministerial Regulation Number 111 of 2016 concerning Technical Guidelines for Regulations in the Village, namely through initiation, socio-political and juridical stages.
\end{abstract}

Keywords: Village Consultative Agency (BPD); Representative Function; Village.

\section{PENDAHULUAN}

Pemerintah Desa merupakan ujung tombak sistem Pemerintahan Daerah yang berhubungan langsung dengan masyarakat. sistem dan mekanisme dari penyelenggaraan Pemerintahan Daerah sangat didukung dan dipengaruhi oleh Pemerintah Desa dan Badan Permusyawaratan Desa (BPD) sebagai bagian dari Pemerintah Daerah. Pada saat era keterbukaan saat ini menuntut peran serta masyarakat untuk berpartisipasi aktif dalam segala aspek kehidupan, melalui Badan Permusyawaratan Desa (BPD) tersebut posisi masyarakat diberikan hak untuk memberikan kontirbusi secara nyata dalam mengurus pembangunan Desa. Anggaran Pendapatan dan Belanja Desa (APBDes) menjadi wahana yang tak terbantahkan dalam upaya membangun pelibatan aktif masyarakat sebab disadari sepenuhnya hanya masyarakat yang bersangkutan, mampu memahami segala kebutuhan.

Pemaknaan Anggaran Pendapatan dan Belanja Desa (APBDes) dipahami sebagai Peraturan Desa yang berisi sumber-sumber penerimaan dan alokasi pengeluaran Desa dalam kurun waktu satu tahun. APBDes terdiri dari bagian Pendapatan Desa, Belanja Desa 
dan Pembiayaan. Alokasi Pengeluaran dalam APBDes dapat meliputi Belanja Pembangunan dan Pos Pengeluaran Rutin.

Badan Permusyawaratan Desa (BPD) secara kelembagaan desa menyangkut lembaga, pihak, atau institusi yang berada di desa yang berasal dari unsur eksekutif, legislatif, dan masyakat yang terlibat dalam penyusunan, pelaksanaan, dan pengawasan APBDes. Komponen pemangku kepentingan tersebut menjadi komponen yang paling mendasar untuk membangun desa dalam rangka mewujudkan partisipasi aktif masyarakat serta penguatan kelembagaan desa yang ada di tengah dinamika perkembangan dan perubahan yang terjadi.

Pemahaman pelaksanaan kelembagaan desa menyangkut proses pengambilan keputusan terdapat dua macam keputusan, yaitu keputusan-keputusan beraspek sosial, yang mengikat masyarakat secara sukarela, tanpa sanksi yang jelas dalam pemaknaan ini lebih dititkberatkan kepada persoalan interaksi sosial yang dibangun oleh kelembagaan desa dan keputusan-keputusan yang dibuat oleh lembaga-lembaga formal desa yang dibentuk untuk melakukan fungsi pengambilan keputusan. Pada titik ini tatanan hukum memiliki peran sangat sentral, hukum masuk dalam segala perspektif kehidupan masyarakat. Penetrasi hukum ke dalam masyarakat yang sedemikian kental, berakibat pada adanya tuntutan untuk melakukan perubahan dan perkembangan dari hukum dan kaitannya dengan masalah-masalah sosial lain juga akan menjadi semakin intensif ${ }^{1}$, untuk itu problem-problem sosial harus ditangani luar biasa oleh hukum dan harus bekerja secara luar biasa pula $^{2}$.Titik tolak pemikiran ini beranjak dari komitmen negara hukum bahwa negara berdasarkan atas hukum yakni, bahwa semua aktivitas kenegaraan hendaknya didasarkan pada hukum ${ }^{3}$. Apalagi mengingat kondisi ada 4 (empat) model hukum, yaitu pertama, model hukum kolonial yang sangat represif; kedua, model hukum pembangunan; ketiga, model hukum progresif; dan keempat, model hukum integratif ${ }^{4}$.

Pada sisi lain norma hukum harus berdimensi pada basis dimana hukum tersebut hidup, diantarnya nilai-nilai kearifan lokal dan salah satu contoh menyangkut keputusan beraspek sosial dititikberatkan kepada bentuk keputusan yang dapat dijumpai dalam

${ }^{1}$ Endang Sutrisno, Bunga Rampai Hukum dan Globalisasi, Genta Press, Yogyakarta, 2009,

${ }^{2}$ Endang Sutrisno, Implementasi Pengelolaan Sumberdaya Pesisir Berbasis Pengelolaan Wilayah Pesisir Secara Terpadu Untuk Kesejahteraan Nelayan. Jurnal Dinamika Hukum, 2014, 14 (1).3.

3 Rahman Yasin, Telaah Putusan MK dalam Sengketa PHPU Pilpres 2004 (Perspektif Negara Demokrasi Konstitusional). Jurnal Konstitusi. 2014, 11 (4).652.

${ }^{4}$ Romli Atmasasmita, Tiga Paradigma Hukum dalam Pembangunan Nasional. Jurnal Hukum Prioris Fakultas Hukum Universitas Trisakti. 2012, 3 (1).5. 
kehidupan sosial masyarakat desa yaitu proses pengambilan keputusan dilakukan melalui proses persetujuan bersama dengan cara musyawarah untuk mufakat berdasarkan nilainilai kearifan lokal yang tumbuh dan berkembang di tengah-tengah masyarakat desa yang bersangkutan.

Adapun pada bentuk keputusan yang berdasarkan pada prosedur yang telah disepakati bersama dalam pengambilan keputusan lebih menitikberatkan pada aspek formalisme, seperti proses Musyawarah Pembangunan Desa (MUSBANGDES) yang dilakukan setiap setahun sekali di Balai Desa. Proses pengambilan keputusan tersebut dilakukan oleh pihak-pihak secara hukum memang diberi fungsi untuk itu, dalam hal menentukan aspek pembebanan hak dan kewajiban yang dibebankan kepada desa sebagai wadah atau organisasi yang berada pada tataran paling bersinggungan secara langsung dengan masyarakat, dan produk hukum dimaksud dikenal dengan Peraturan Desa (PerDes), sebagai tatanan norma yang berada pada tingkat produk hukum di desa yang ditetapkan oleh Kepala Desa dan Badan Permusyawaratan Desa pada konteks penyelenggaraan Pemerintahan Desa untuk tujuan penyelenggaraan pemeritah desa ${ }^{5}$.

Dalam lintasan kronologi perjalanan keberadaan institusi Badan Perwakilan Desa (BPD) yang ada selama ini berubah namanya menjadi Badan Permusyawaratan Desa. Pada sisi lain Badan Perwakilan Desa (BPD) tersebut dibebankan dengan kewajiban untuk merumuskan Peraturan Desa bersama Kepala Desa, menampung dan menyalurkan aspirasi masyarakat sebagai bentuk partisipasi aktif warga masyarakat desa untuk memenuhi kebutuhannya dalam rangka membangun desa, jadi eksistensi Badan Perwakilan Desa (BPD) sebagai institusi yang menjalankan peran badan permusyawaratan berasal dari masyarakat desa, disamping berperan aktif dibebankan dengan fungsi sebagai jembatan penghubung antara Kepala Desa dengan Masyarakat desa, fungsinya menjalankan peran representasi ${ }^{6}$.

Wilayah fokus kajian menyangkut Badan Permusyawaratan Desa yang berada di Kabupaten Tegal. Deskripsi awal menunjukan bahwa peranan kelembagaan desa dalam menyusun APBDes untuk beberapa hal peran tersebut telah dijalankan sesuai tujuan yang diharapkan, tetapi masih ditemukan adanya hambatan pada saat fungsi Badan

\footnotetext{
5 Kushandajani, Otonomi Desa Berbasis Modal Sosial Dalam Perspektif Socio Legal. FISIP UNDIP, Semarang. 2008, 70-71.

6 Sadu Wasistiono, M.Irawan Tahir, Prospek Pengembangan Desa. Bandung: CV Fokus Media, 2007.
} 
Permusyawaratan Desa ini menjalankan perannya. Hal ini cukup beralasan sebab Kepala Desa pada akhirnya memiliki peran dominan, terutama dalam penyusunan APBDes. Beberapa tokoh masyarakat yang masuk dalam keanggotaan Badan Permusyawaratan Desa masih merasa belum dilibatkan secara maksimal dalam penyusunan APBDes tersebut, padahal menurut mereka penyusunan APBDes sangatlah penting dalam pembangunan desa untuk kesejahteraan rakyat.

Kajian penelitian diarahkan pada peranan Badan Permusyawaratan Desa (BPD) dalam menyusun dan APBDes di Era Otonomi Daerah. Permasalahan yang muncul adalah Badan Permusyawaratan Desa (BPD) tidak melaksanakan fungsinya secara optimal untuk mewujudkan APBDes yang partisipatif, forum BPD menjadi elit desa semata dimana saluran aspirasi masyarakat terhambat terutama dalam penyusuanan APBDes yang memerlukan pembahasan secara partisipatif begitu juga pengawasannya sebagaimana salah satu tugas BPD menggali, menampung, menghimpun, merumuskan dan menyalurkan aspirasi masyarakat. Kondisi realitas sosial tersebut menimbulkan pertanyaan mendasar yaitu bagaimanakah tatanan hukum mengatur persoalan Badan Permusyawaratan Desa (BPD) pada perspektif penyusunan Anggaran Pendapatan dan Belanja Desa (APBDes) berdasarkan dasar hukum Peraturan Pemerintah Nomor 72 Tahun 2005 tentang Desa, dan pada sisi lain bagaimanakah hambatan yang dihadapi oleh Badan Permusyawaratan Desa (BPD) dalam menjalankan tugasnya untuk menyusun Anggaran Pendapatan dan Belanja Desa (APBDes) tersebut. Hal ini yang harus mendapatkan perhatian dalam kajian ini sebab Badan Permusyawaratan Desa (BPD) memiliki peran strategis guna mewujudkan pembangunan desa yang berbasis kepada aspek peranserta masyarakat, ada unsur pelibatan masyarakat secara genuine, sehingga formulasi kebijakan yang harus dibangun bermuatan nilai-nilai bottom up.

Badan Permusyawaratan Desa (BPD) merupakan bagian dari pelaksana tugas dan kewajiban yang dilakukan sesuai dengan status dalam struktur pemerintahan yang ada di desa, dan memiliki posisi yang sentral dalam pengambilan keputusan, hal tersebut disebabkan posisi BPD sebagai penyalur aspirasi masyarakat dan merupakan mitra dari Kepala Desa dalam penyusunan kebijakan yang ada di desa tersebut.

\section{METODE}

Berdasarkan permasalahan yang dikemukakan, pendekatan penelitian yang digunakan yaitu penelitian hukum normatif didasarkan pada pertimbangan tujuan 
penelitian untuk mengkaji berbagai peraturan yang berkaitan dengan Peran BPD dan Peraturan Desa. Penelitian ini memiliki sasaran utama yang menjadi objek penelitian adalah guna mengetahui proses penyusunan dan penetapan Peraturan Desa. Penelitian ini juga bertujuan mengetahui implementasi kebijakan legalisasi tentang fungsi Badan Permusyawaratan Desa (BPD) dalam perumusan kebijakan peraturan desa, serta guna mengetahui proses atau tahapan yang ideal dalam penyusunan peraturan desa di Desa yang berada di Kecamatan Dukuhturi Kabupaten Tegal. BPD merupakan bagian dari pelaksana tugas dan kewajiban yang dilakukan sesuai dengan status dalam struktur pemerintahan yang ada di desa. Jenis penelitiannya menggunakan penelitian kualitatif untuk memahami hubungan kelembagaan Kepala Desa, BPD dan BUMDes untuk percepatan pembangunan kesejahteraan masyarakat desa. Kedalaman untuk menelaah realitas sosial terhadap keberlakuan produk perundang-undangan Badan Permusyawaratan Desa (BPD) menjadi kebutuhan yang tak terelakan sebab dalam ranah penelitian kualitatif ini, realitas yang terdeskripsikan harus dapat dikaji secara dalam guna membangun pemahaman terhadap norma hukum yang berlaku, hal ini sangat beralasan oleh sebab tatanan hukum tidaklah mungkin terlepas dari tataran konteks. Hukam dipandang tidak hanya sekedar kumpulan teks-teks, tertulis.

\section{LANDASAN TEORITIS}

Keterkaitan yang ada antara komponen masyarakat dengan hukum sebagai satu kesatuan yang tak terpisahkan sebab norma hukum hidup, tumbuh berkembang di tengahtengah masyarakat dan tata hukum lebih dimaksudkan untuk berlaku sebagai social order dengan merujuk kepada konsep ubi societas ibi ius, mengandung makna eksistensi masyarakat ditengarai didalamnya ditemukan tatanan norama hukum yang mengatur masyarakat dimaksud, biasa disebutkan dimana ada masyarakat disitulah ada norma hukum. Berlandaskan kepada pernyataan tersebut memberikan suatu simpulan yang menyebutkan kaidah hukum bermuatan fungsi untuk mengatur tata kehidupan masyarakat (social order) dalam melakukan interaksi sosial untuk membangun kesejahteraan sebagaimana yang diamanatkan melalui Pembukaan UUD Negara RI Tahun $1945^{7}$. Terkait upaya mewujudkan sistem hukum yang efektif perlu penataan kembali kelembagaan hukum yang didukung oleh kualitas sumber daya manusia dan kultur dan kesadaran hukum masyarakat yang terus meningkat, seiring dengan pembaharuan materi

\footnotetext{
${ }^{7}$ Juniarso Ridwan, Achmad Sodik Sudrajat, Hukum Administrasi Negara dan Kebijakan Pelayanan Publik. Bandung: Nuansa. 2009.
} 
hukum yang terstruktur secara harmonis tanpa pertentangan dan tumpang tindih dan hukum secara terus menerus diperbaharui sesuai dengan tuntutan perkembangan kebutuhan ${ }^{8}$. Sectors of life governed by the rule of law must be able to reach the point of order and a sense of justice, including economic management, human resources and natural resources in order to achieve happiness together ${ }^{9}$. Perlu disadari bahwa untuk menciptakan keadilan hukum diperlukan peran aktif dari berbagai pihak mulai dari pembentukan produk hukum hingga penegakan produk hukum ${ }^{10}$. Hal ini sangat disadari sepenuhnya mengingat sejauh ini pembangunan hukum di negeri ini cenderung bergerak dalam ruang yang artifisial dan tanpa $\operatorname{arah}^{11}$. Indonesia today is faced with a very "unique" problem of law performance regarding the formal truth treated as the most dominant consideration of legal decision embracing reine Rechtslehre Kelsenian's way of thinking. An approach that is still in further discussion through a more holistic alternative paradigm $^{12}$. Mengingat dalam ajaran positivisme hukum yang bersifat monistik, dimana hanya mengakui satu macam keadilan, yaitu keadilan yang lahir dari hukum positif ${ }^{13}$.

Berdasarkan deskripsi tersebut dapat disimpulkan keberadaan hukum sangat dibutuhkan untuk kehidupan masyarakat, tetapi dalam perspektif lain harus diperhatikan pula fakta sosial tentang keberadaan kepentingandalam masyarakat sebagai sebuah varian yang dapat mempengaruhi proses bekerjanya hukum di tengah-tengah masyarakat yang berakibat kepada benturan kepentingan di antara keterkaitan tatanan hukum dan masyarakat. Intinya pertentangan yang terjadi dapat diantisipasi manakala kaidah hukum yang diberlakukan dapat dikembalikan kepada tataran konsep awal untuk tujuan yang hakiki dari hukum yaitu keadilan, kepastian hukum, kemanfaatan, kesejahteraan, ketertiban sosial. The existence of laws in the society is to integrate and coordinate the interests of

8 Bahria Prentha, Filsafat Hukum dan Nilai-Nilai Pancasila. Jurnal Ilmiah Kebijakan Hukum. Pusat Pengkajian dan Pengembangan Kebijakan Kementerian Hukum dan HAM RI, 2011, 5 (2).177.

9 Endang Sutrisno, Sudarminto, Legal Culture of Fisherman Communities in Indonesia (Studies in Cirebon Coastal Fishing Communities in the Northern Coast of West Java, Indonesia. International Journal of Current Advanced Research. 2017, 6 (2).2249-2253.

10 Yunus Bureni, Moralitas Pembentukan Peraturan Daerah dalam Upaya Mencapai Keadilan Substantif (Morality Formation of Local Regulations in An Effort to Ensure Substantive Justice). Jurnal Legislasi Indonesia. 2013, 10 (20). 125.

11 Dayanto, Rekonstruksi Paradigma Pembangunan Negara Hukum Indonesia Berbasis Pancasila, Jurnal Dinamika Hukum. 2013, 13 (3).498.

12 Endang Sutrisno, Tracing the Performance of Law in Indonesia (A Perspective of Thomas Kuhn's "Normal Science", Journal of Law, Policy and Globalization. International Institute for Science, Technology \& Education Accelerating Global Knowledge Creation and Sharing. 2015, 37.126.

13 Ibnu Artadi, Dekonstruksi Pemahaman Penyelesaian Sengketa Bisnis (Ekonomi dan Keuangan) Beraspek Pidana melalui Prosedur Perdamaian: Menuju Proses Peradilan Pidana Rekonsiliatif. Jurnal Hukum Responsif Fakultas Hukum Universitas`Swadaya Gunung Jati Cirebon. 2011, 1. (1).33-34. 
people that might conflict against each other. Laws must be able to prevent the conflicts as effectively as possible ${ }^{14}$.

Fungsi kelembagaan hukum menjadi sangat penting sehingga organ-organ lembaga hukum yang ada harus berdasarkan kepada kaidah hukum yang berlaku. Hal ini sesuai dengan keberadaan Badan Permusyawaratan Desa (BPD) yang melandasi proses pengambilan kebijakan yang dilakukan pada tataran aparatur desa, harus sepenuhnya mengakomodir kepentingan masyarakat desa, dapat disimpulkan sifat responsif organ kelembagaan hukum melalui Badan Permusyawaratan Desa (BPD) menjadi tak terelakan. Wadah kelembagaan hukum harus mampu membangun jiwa partisipatif warga masyarakat desa untuk mengatur kemandirian warga guna memberdayakan masyarakatnya menuju pembangunan desa yang dikehendaki sesuai dengan aspirasi warganya.

Benturan kepentingan yang ada dalam norma hukum harus mampu diselesaikan melalui proses yang tidak mengganggu harmonisasi pada titik inilah norma dasar Pancasila memiliki fungsi yang strategis guna menjadi katalisator titik temu perbedaan pandangan dan kepentingan yang terjadi hal ini dalam persepktif filosofis. Pancasila sebagai norma dasar grundnorm pada tataran tertinggi keberlakuan tatanan kaidah hukum. Pada sisi faktor sosiologis tatanan hukum dibutuhkan oleh masyarakat sebagai kebutuhan pokok yang bertujuan membangun tertib sosial dalam relasi antara warga masyarakat dengan organ kelembagaan hukum. Relasi yang dibangun antara Badan Permusyawaratan Desa (BPD) dengan masyarakat desa harus tetap mengacu kepada norma hukum yang melandasinya. The protection of society has many different dimensions, one of which is a legal protection. A legal protection for every citizen of Indonesian, without exception, can be found in the 1945 Constitution of the Republic of Indonesia ${ }^{15}$.

Pada sudut pandang lain tatanan hukum mampu dipandang pada aspek sebagai sarana yang dapat mengatur interaksi kehidupan bermasyarakat sehingga kebutuhan masyarakat dapat terpenuhi. Hukum selain berfungsi untuk mencegah terjadinya konflik, juga untuk mngatur kebutuhan agar kebutuhan masyarakat terapenuhi. The law must not be seen as a finite scheme, but it must continue to move, change, adapt to the dynamics of

\footnotetext{
${ }^{14}$ Hertogh, Marc, A European Conception of Legal Consciousness: Rediscovering Eugen Ehrlich. Journal of Law and Society. 2004, 31 (4).4.

${ }^{15}$ Hasbir Paserangi, Geographical Indications Protection "Pulut Mandoti Rice" as an Alternative of People Economic Empowerment. Journal of Law, Policy and Globalization. International Institute for Science, Technology \& Education Accelerating Global Knowledge Creation and Sharing. 2016, 54.143.
} 
human life $e^{16}$. Keberadaan norma hukum yang mengatur Badan Permusyawaratan Desa (BPD) telah menempatkan organ desa ini pada tataran untuk membangun kesejahteraan masyarakat desa dengan berlandaskan kepada aspek partisipasi, kemandirian, pemberdayaan serta responsif warga masyarakat desa. Fungsi hukum pada satu sisi digunakan untuk mengubah kehidupan masyarakat agar menjadi lebih baik dan pada sisi lain norma hukum dituntut untuk mempertahankan pola susunan masyarakat yang telah eksis ada dan tatanan hukum melegitimasi perubahan-perubahan yang terjadi di masa lalu ${ }^{17}$.

Keberadaan Badan Permusyawaratan Desa (BPD) yang semula berasal dari Badan Perwakilan Desa telah mempertegas argumentasi tersebut, meskipun pada akhirnya gerak dinamika perkembangan Badan Permusyawaratan Desa (BPD) ini sangat bergantung kepada pemahaman masyarakat dan sikap masyarakat untuk mengoptimalkan fungsi Badan Permusyawaratan Desa (BPD) sebagai bagian dalam proses pembangunan desa.

Esmi Warassih telah dengan tegas menegaskan bahwa hukum sebagai sistem norma dalam perkembangannya tidak hanya dipergunakan untuk mengatur dan mempertahankan pola tingkah laku yang sudah ada, melainkan lebih dari itu, hukum juga dibutuhkan sebagai sarana pengarah dalam merealisasikan kebijaksanaan Negara dalam bidang sosial, budaya, ekonomi, politik pertahanan dan keamanan nasional. Cita atau ide hukum sesungguhnya diperlukan untuk membangun kehidupan masyarakat yang demokratis, hal tersebut berarti bahwa institusi hukum dituntut untuk menjadi bintang pemandu yang dapat menjadi penuntut bagi para pembuat/pengambil kebijaksanaan dalam proses pembuatan dan pengimplementasian kebijaksanaan publik yang adil dan demokratis ${ }^{18}$. Kedudukan kaidah hukum yang mengatur Badan Permusyawaratan Desa (BPD) memposisikan norma hukum sebagai sarana untuk menjadi pengarah serta merealisiasikan kebijaksanaan Negara, ada pengakuan tentang legalitas Badan Permusyawaratan Desa (BPD) ini sebagai organ yang dimiliki oleh pemerintahan desa sebagai perangkat aparatur organ kelembagaan yang berada pada lapisan bawah dari bentuk pemerintahan yang mewakili Negara ditingkat desa.

Keberadaan Badan Permusyawaratan Desa (BPD) menjadi penegasan tentang

\footnotetext{
${ }^{16}$ Muhammad Irawan dkk, The Role of Judges in Realizing Justice: A Criminal Justice Perspective. Journal of Law, Policy and Globalization. International Institute for Science, Technology \& Education Accelerating Global Knowledge Creation and Sharing. 2018, 76.114.

${ }^{17}$ Satjipto Rahardjo, Ilmu Hukum. Bandung: Alumni, 2000.

${ }^{18}$ Esmi Warassih, Pranata Hukum Sebuah Telaah Sosiologi. Semarang: PT Suryandaru Utama, 2005.
} 
kehendak politik (political will) negara untuk mengakui intervensi aspek kepentingan politik pemerintah guna pemberdayaan kelembagaan ditingkat desa dengan mengusung nilai-nilai partsipasi masyarakat desa, nilai kemandirian warga desa dan nilai responsivitas kebijaksanaan negara (policy) untuk membangun ke arah yang lebih baik sesuai dengan fungsi hukum dalam proses pembangunan, namun pada akhirnya hukum tidak mungkin dapat dipisahkan dengan politik, terutama pada masyarakat yang sedang membangun dimana pembangunan merupakan keputusan politik sedangkan pembangunan jelas-jelas membutuhkan legalitas dari sektor hukum ${ }^{19}$. Pada dasarnya hukum tidak dapat terbebas dari subsistem kemasyarakatan lainnya, politik kerap kali melakukan intervensi atas pembuatan dan pelaksanaan hukum. Dalam hubungan timbal balik antara politik dan hukum, maka hukumlah yang terpengaruh oleh politik, karena subsitem politik memiliki kosentrasi energi yang lebih besar dari pada hukum.

Otonomi Desa dalam pandangan masyarakat desa tidaklah hanya sekedar mendeskripsikan pada pemahaman pemerintah desa, menyangkut pula otonomi desa untuk menentukan nasibnya sendiri serta meliputi aspek pengelolaan sumber daya alam yang dimiliki oleh desa dengan tujuan membangun masyarakat yang sejahtera melalui semangat otonomi desa yaitu membangun inisatif dari desa, sebagai pengejawantahan dari kebebasan untuk menentukan dirinya serta melalui aspek pelibatan masyarakat desa secara utuh, dimulai pada saat perumusan kebijaksanaan sampai dengan implementasi kebijaksanaan, yang tentunya dalam proses tersebut harus disyaratkan monitoring dan evaluasi terhadap kebijaksanaan desa untuk pembangunan serta kegiatan-kegiatan lain penunjang yang dirasakan oleh masyarakat desa. Komponen inisiatif dan partisipasi aktif masyarakat desa dalam pengambilan keputusan (policy) sebagai bentuk isu global yang harus dialami sebagai wujud dari nilai transparansi, nilai-nilai positif tersebut menjadi modal awal pembangunan desa dalam wujudnya yang dipandang sebagai social capital masyarakat desa. Alasan ini, cukup logis mengingat eksistensi sebuah desa dengan berpedoman kepada konsep komunitas, bahwa persepsi tentang desa tidak hanya merupakan kesatuan teritorial sebuah unit wilayah, tetpai juga dipandang sebagai kelompok sosial yang didalamnya terkandung muatan nilai-nilai sistem sosial, dalam wujudnya yang teridentifikasikan pada bentuk kerja interaksi antar seluruh komponen masyarakat, kondisi ini semakin memberikan nilai tambah sebab masyarakat Indonesia memiliki kecenderungan kehidupan desa yang dilingkupui dengan nilai-nilai gotong royong, kesetiaan sosial, kepedulian

${ }^{19}$ Ahmad Ali, Menguak Tabir Hukum (Suatu Kajian Sosiologis dan Filosofis), Jakarta: PT Toko Gunung Agung, 2002. 
sosial, kesalehan sosial yang dapat dijadikan modal sosial positif guna membangun desanya. Pada perspektif lain keberadaan otonomi desa dipahami pada sudut pandang yang berbeda yaitu pemberian otonomi yang seluas-luasnya dalam konteks menjaga keutuhan integrasi sebagai sebuah bangsa dengan filosofi Negara Kesatuan Republik Indonesia (NKRI).

Perubahan kebijakan tentang penyelenggaraan pemerintahan daerah (termasuk pemerintahan desa) dari UndangUndang Nomor 5 Tahun 1974 dan UndangUndang Nomor 5 Tahun 1979 menjadi Undang-Undang Nomor 22 Tahun 1999, Undang-Undang Nomor 32 Tahun 2004 serta yang terbaru dengan adanya perubahan Undang-Undang Pemerintahan Daerah melalui penetapan Undang-Undang Nomor 12 Tahun 2008.

Pemerintahan Daerah melalui penetapan Undang-Undang Nomor 12 Tahun 2008 tentang Perubahan Kedua Atas Undang-Undang Nomor 32 Tahun 2004 tentang Pemerintahan Daerah, membawa implikasi yang sangat besar. Salah satu implikasi tersebut adalah bahwa desa tidak sekedar merupakan wilayah administratif sebagai kepanjangan tangan pemerintahan pusat di daerah (pelaksana asas dekonsentrasi), tetapi memiliki lebih merupakan kesatuan masyarakat hukum yang memiliki otonomi luas (Kartohadikoesoema, 1984). Dalam ketentuan Pasal 1 Undang-Undang Nomor 9 Tahun 2015 tentang Perubahan Kedua Atas Undang-Undang Nomor 23 Tahun 2014 tentang Pemerintahan Daerah menyebutkan beberapa ketentuan dalam Undang-Undang Nomor 23 Tahun 2014 tentang Pemerintahan Daerah (Lembaran Negara RI Tahun 2014 Nomor 244, Tambahan Lembaran Negara RI Nomor 5587) sebagaimana telah diubah dengan Undang-Undang Nomor 2 Tahun 2015 tentang Penetapan PeraturanPemerintah Pengganti Undang-Undang Nomor 2 Tahun 2014 tentang Perubahan Atas Undang-Undang Nomor 23 Tahun 2014 tentang Pemerintahan Daerah Menjadi Undang-Undang (Lembaran Negara RI Tahun 2015 Nomor 24, Tambahan Lembaran Negara RI Nomor 5657).

Kumpulan individu-individu yang membentuk desa dan merupakan sebuah daerah hukum ini, secara alami memiliki otonomi yang sangat luas, lebih luas dari pada otonomi daerah-daerah hukum diatasnya yang lahir di kemudian hari, baik yang terbentuk oleh bergabungnya desa-desa dengan sukarela atau yang dipaksakan oleh pihak-pihak yang lebih kuat. Otonomi desa meliputi hak untuk menentukan sendiri hidup matinya desa itu, dan hak untuk menentukan batas daerahnya sendiri.

Era Reformasi pada tahun 1998 di Indonesia, penyelenggaraan pemerintahan di daerah juga menjadi salah satu sasaran reformasi. Revisi Undang-Undang Nomor 5 Tahun 
1974 dan Undang-Undang Nomor 5 Tahun 1979 menjadi tidak terhindarkan lagi, sehingga terbitlah Undang-Undang Nomor 22 Tahun 1999 tentang Pemerintahan Daerah yang sekaligus mengatur Daerah Otonom dan Desa dalam satu paket, selanjutnya dalam perjalananya di revisi kembali menjadi Undang-Undang Nomor 32 Tahun 2004 serta diubah kemabali menjadi Undang-Undang Nomor 12 Tahun 2008. Bahwa Undang-Undang Nomor 12 Tahun 2008 tersebut tidak saja mengatur dan sekaligus membawa perubahan di daerah (provinsi, kabupaten dan kota), Namun juga memberikan landasan terhadap perubahan yang mendasar pada desa. Salah satu perubahan mendasar dalam pengaturan mengenai desa adalah munculnya BPD (Badan Permusyawaratan Desa) yang merupakan lembaga tersendiri dan memiliki fungsi yang sangat luas seperti mengayomi adatisitiadat, membuat Peraturan Desa, menampung dan menyalurkan aspirasi masyarakat serta melakukan pengawasan terhadap penyelenggaraan Pemerintahan Desa ${ }^{20}$.

Dalam norma hukum Peraturan Pemerintah Nomor 72 Tahun 2005 tentang Desa, bahwadesa yang pada awalnya didefinisikan sebagai suatu wilayah yang ditempati oleh sejumlah penduduk sebagai kesatuan masyarakat termasuk didalamnya kesatuan masyarakat hukum yang mempunyai organisasi pemerintahan terendah langsung dibawah camat, berubah rumusanya menajdi kesatuan masyarakat hukum yang memiliki kewenangan untuk mengatur dan mengurus kepentingan masyarakat setempat berdasarkan asal usul dan adat istiadat setempat.

Dalam pemikiran konsep dengan berdasarkan aspek yuridis formal maupun fungsinya, memang terdapat perbedaan yang cukup substantif antara Lembaga Musyawarah Desa (LMD) dan Badan Permusyawaratan Desa (BPD). Dalam Lembaga Musyawarah Desa (LMD) memiliki fungsi legislasi saja, sementara Badan Permusyawaratan Desa (BPD) selain berfungsi legislasi juga berfungsi mengontrol pemerintahan desa, dan juga menampung dan menyalurkan aspirasi masyarakat. Merujuk pada Undang-undang Nomor 32 Tahun 2004 dan Undang-Undang Nomor 12 tahun 2008, bahwa telah ditegaskan didalam norma tersebut desa adalah kesatuan masyarakat hukum yang memiliki batas-batas wilayah yuridiksi, berwenang untuk mengatur dan mengurus kepentingan masyarakat setempat berdasarkan asal usul dan adat istiadat setempat yang diakui dan/atau dibentuk dalam sistem pemerintahan nasional dan berada di kabupaten/kota. Landasan pemikiran dalam pengaturan mengenai desa adalah

\footnotetext{
${ }^{20}$ Sadu Wasistiono, M.Irawan Tahir, Prospek Pengembangan Desa. Bandung: CV Fokus Media, 2007.
} 
keanekaragaman, partisipasi, ekonomi, otonomi asli, demokratisasi dan pemberdayaan masyarakat.

Sebagai perwujudan demokrasi, dalam penyelenggaraan pemerintahan desa, dibentuk Badan Permusyawaratan Desa (BPD) ataupun sebutan lain yang sesuai dengan budaya yang berkembang di desa bersangkutan, yang berfungsi sebagai lembaga pengaturan dalam penyelenggaraan pemerintahan desa, seperti pembuatan dan pelaksanaan peraturan desa, anggaran pendapatan dan belanja desa, keputusan kepala desa. Didesa dibentuk lembaga kemasyarakatan yang berkedudukan sebagai mitra kerja pemerintahan desa dalam memberdayakan masyarakat desa.

Pemerintah Desa terdiri atas kepala desa dan perangkat desa lainya. Kepala desa dipilih langsung oleh dan dari penduduk desa tersebut. Pemilihan kepala desa dalam kesatuan masyarakat hukum adat beserta hak tradisionalnya sepanjang masih hidup dan yang diakui keberadaanya berlaku ketentuan hukum adat setempat. Jabatan kepala desa adalah enam tahun dan dapat dipilih kembali hanya satu kali masa jabatan berikutnya. Sangatlah jelas berdasar ketentuan mengenai desa, yaitu desa di era reformasi sekarang mempunyai kewenangan dan diakui sebagai salah satu daerah yang memiliki "kekuatan" dengan nama otonomi desa. Dengan adanya "kekuatan" ini desa memperoleh kekuasaan dalam menentukan kebijakan dalam berprakarsa dan berinisiatif sesuai dengan potensi yang dimiliki, baik sumber daya manusia dan sumber daya alamnya untuk berkembang sesuai dengan ketentuan peraturan perundang-undangan yang berlaku. Mengenai hal itu dapat diperoleh penjelasan terkait kewenangan desa. Menurut ketentuan Peraturan Menteri Dalam Negeri Nomor 30 Tahun 2006 tentang Tata Cara Urusan Pemerintahan Kabupaten/ Kota Kepada Desa, urusan pemerintahan yang menjadi kewenangan desa mencakup:

1) urusan pemerintahan yang sudah ada berdasarkan hak asal usul desa;

2) urusan pemerintahan yang menjadi kewenangan kabupaten/ kota yang diserahkan pengaturannya kepada desa;

3) tugas pembantuan dari pemerintah, pemerintah provinsi dan/atau pemerintah kabupaten/kota;

4) urusan pemerintahan lainya yang oleh peraturan perundang-undangan diserahkan kepada desa.

Tugas pembantuan yang berasal dari pemerintah, pemerintah propinsi, dan/atau pemerintah kabupaten/kota kepada desa, harus disertai dengan pembiayaan, sarana dan prasarana, serta sumber daya manusia sehingga tugas tersebut dapat terlaksana dengan 
baik. Badan Permusyawaratan Desa (BPD) berfungsi menetapkan Peraturan Desa bersama Kepala Desa dengan masukan dari aspirasi masyarakat. Anggota BPD adalah wakil dari penduduk Desa bersangkutan yang ditetapkan dengan cara musyawarah dan mufakat, sedangkan pimpinan Badan Permusyawaratan Desa (BPD) dipilih dari dan oleh anggota Badan Permusyawaratan Desa (BPD) yang masa jabatannya adalah enam tahun dan dapat dipilih kembali untuk satu kali masa jabatan berikutnya. Lembaga kemasyarakatan di desa yang ditetapkan dengan peraturan desa, yang bertugas membantu pemerintah desa dan merupakan mitra dalam memberdayakan masyarakat desa. Yang dimaksud dengan kemasyarakatan desa, seperti Rukun Tetangga (RT), Rukun Warga (RW), Pendidikan Kesejahteraan Keluarga (PKK), Karang Taruna dan Lembaga Pemberdaya Masyarakat. Keuangan Desa ialah semua hak dan kewajiban desa yang dapat dinilai dengan uang, serta segala sesuatu baik berupa uang maupun berupa barang yang dapat dijadikan milik desa berhubung dengan pelaksanaan hak dan kewajiban. Keuangan desa tersebut diperoleh dari sumber pendapatan desa. Terdiri dari Pendapatan Asli Desa (PAD), bagi hasil pajak daerah dan retribusi daerah Kabupaten/Kota, bagian dari dana perimbangan keuangan pusat dan daerah yang diterima oleh Kabupaten/Kota, serta bantuan lain dari pemerintah, Pemerintah Provinsi dan Pemerintah Kabupaten/Kota, termasuk pula hibah dan sumbangan dari pihak ketiga. Sumbangan adalah pemberian dari pihak ketiga, dapat berbentuk hadiah, donasi, wakaf dan/atau sumbangan lain serta pemberian sumbangan dimaksud tidak mengurangi kewajiban-kewajiban pihak penyumbang. Belanja Desa digunakan untuk membiayai penyelenggaraan pemerintahan desa dan pemberdayaan masyarakat desa. Pengelolaan keuangan desa dilakukan oleh kepala desa yang dituangkan dalam peraturan desa tentang anggaran pendapatan dan belanja desa, sebagaimana diatur dalam Permendagri No.113 Tahun 2014 Tentang Pengelolaan Keuangan Desa.

\section{HASIL DAN PEMBAHASAN}

Badan Perwakilan Desa (BPD) yang ada selama ini berubah namanya menjadi Badan Permusyawaratan Desa (BPD) berfungsi menetapkan Peraturan Desa bersama kepala Desa, menampung dan menyalurkan aspirasi masyarakat.

Perubahan ini didasarkan pada kondisi faktual bahwa budaya politik lokal yang berbasis pada filosofi "musyawarah untuk mufakat". Musyawarah berbicara tentang proses, sedangkan mufakat berbicara tentang hasil. Hasil yang baik diharapkan diperoleh dari proses yang baik. Melaiui musyawarah untuk mufakat, berbagai konflik antara para elit

politik dapat segera diselesaikan secara arif, sehingga tidak sampai menimbulkan 
goncangan-goncangan yang merugikan masyarakat luas. Dalam pasal 29 Peraturan Pemerintah Nomor 72 Tahun 2005 Badan Permusyawaratan Desa berkedudukan sebagai unsur penyelenggara Pemerintah Desa. Keanggotaan BPD seperti yang disebutkan dalam Pasal 30 Peraturan Pemerintah Nomor 72 Tahun 2005 adalah wakil dari penduduk Desa bersangkutan berdasarkan keterwakilan wilayah. Anggota BPD terdiri dari Ketua Rukun Warga, pemangku adat, golongan profesi, pemuka agama dan tokoh atau pemuka masyarakat lainnya. Masa jabatan anggota BPD adalah 6 (enam) tahun dan dapat diangkat/diusulkan kembali untuk 1 kali masa jabatan berikutnya. Pimpinan dan Anggota BPD tidak diperbolehkan merangkap jabatan sebagai Kepala Desa dan Perangkat Desa. BPD berfungsi menetapkan Peraturan Desa bersama Kepala Desa, menampung dan menyalurkan aspirasi masyarakat. Adapun jumlah anggota BPD ditetapkan dengan jumlah ganjil, paling sedikit 5 (lima) orang dan paling banyak 11 (sebelas) orang, dengan memperhatikan luas wilayah, jumlah penduduk dan kemampuan keuangan Desa (Pasal 31 Peraturan Pemerintah Nomor 72 tahun 2005).

Dalam Pasal 3 Peraturan Daerah (PERDA) Kabupaten Tegal Nomor 13 Tahun 2006 disebutkan bahwa BPD merupakan mitra Pemerintah Desa yang berfungsi bersamasama dengan Pemerintah Desa menetapkan kebijakan Desa dalam bentuk Peraturan Desa, menampung dan menyalurkan aspirasi masyarakat, disamping itu BPD rnempunyai fungsi mengawasi pelaksanakan peraturan Desa dalam rangka pemantapan pelaksanaan kinerja pemerintah Desa. Dan dalam Pasal 4 PERDA Kabupaten Tegal Nomor 13 Tahun 2006, dijelaskan BPD rnempunyai wewenang:
a. membahas dan Menetapkan Rancangan Peraturan Desa bersama Kuwu;
b. melaksanakan pengawasan terbadap pelaksanaan Peraturan Desa atau Peraturan Kuwu dan Keputusan Kuwu;
c. mengusulkan Pengangkatan dan pemberhentian Kuwu;
d. membentuk Panitia Pemilihan Kuwu;
e. menggali, menampung, menghimpun, merumuskan dan menyalurkan aspirasi masyarakat; dan
f. menyusun tata tertib.

Dan dalam Pasal PERDA Kabupaten Tegal Nomor 13 Tahun 2006, Anggota BPD rnempunyai hak:
a. mengajukan Rancangan Peraturan Desa;
b. mengajukan pertanyaan;
c. menyampaikan usul dan pendapat;
d. memilih dan dipitfh sebagai Pimpinan BPD;
e. memperoleh tunjangan sesuai dengan kemampuan Keuangan Desa dan/atau ketentuan peraturan perundang-undangan.
Dalam proses pengambilan keputusan di Desa ada dua macam keputusan, Pertama 
keputusan-keputusan yang beraspek sosial, yang mengikat masyarakat secara sukarela, tanpa sanksi yang jelas, Kedua keputusan-keputusan yang dibuat oleh lembaga-lembaga formal Desa yang dibentuk untuk melakukan fungsi pengamabilan keputusan. Untuk bentuk keputusan pertama, banyak dijumpai dalam kehidupan sosial masyarakat Desa, proses pengambilan keputusan dilakukan melalui proses persetujuan bersama, sebelumnya alasan-alasan untuk pemilihan alternatif diuraikan terlebih dahulu oleh para tetua Desa ataupun orang yang dianggap memiliki kewibawaan tertentu. Adapun pada bentuk kedua keputusan-keputusan didasarkan pada prosedur yang telah disepakati bersama, seperti proses Musyawarah Pembangunan Desa (Musbangdes) yang dilakukan setiap setahun sekali di Balai Desa.

Beberapa ketentuan yang berkaitan dengan tugas dan wewenang dari Badan Pemusyawatan Desa (BPD) yaitu :

a. Peraturan Pemerintah Nomor 72 Tahun 2005 Tentang Desa;

b. Peraturan Pemerintah Nomor 73 Tahun 2005 Tentang Kelurahan;

c. Peraturan Dalam Negeri Nomor 29 tahun 2006 Tentang Pedoman

d. Pembentukan dan Mekanisme Penyusunan dan Peraturan Desa;

e. Peraturan Pemerintah Nomor 41 Tahun 2007 tentang Organisasi

f. Perangkat Desa;

g. Peraturan Menteri dalam Negeri Nomor 37 Tahun 2007 tentang Pedoman Pengelolaan Keuangan Desa;

Sebagai tindak lanjut dari Undang-Undang Nomor 32 Tahun 2004 Tentang Pemerintah Daerah, khususnya Pasal 127 serta Pasal 216 bahwa pengaturan lebih lanjut mengenai Kelurahan dan Desa ditetapkan dalam Peraturan Daerah yang berpedoman pada Peraturan Pemerintah, Desa Ketanggungan Kecamatan Dukuhturi Kabupaten Tegal, telah berhasil menyusun peraturan sesuai dengan ketentuan yang berlaku, khususnya yang berhubungan dengan Badan Permusyawaratan Desa (BPD) sebagai badan legislatif yang berwenang untuk menyusun regulasi diantaranya tentang APBDes. Struktur penyusunan hukum didasarkan dari pembagian kekuasaan antara legislatif, yudikatif dan eksekutif. Struktur tersebut tidak mampu berdiri sendiri, namun merupakan bagian dari penataan ketatanegaraan yang lebih luas. Pemisahan aktivitas dari ketatanegaraan menjadi tiga yaitu legislatif, yudikatif dan eksekutif, pembuatan hukum akan berjalan pada proses yang eksklusif. Peran dari BPD dalam menyelenggarakan Pemerintahan Desa dimulai pada saat proses perencanaan yang ditandai dengan kegiatan menampung aspirasi masyarakat dan membentuk Peraturan Desa (PERDES). Setelah PERDES disusun selanjutnya BPD bertugas melakukan pengendalian dalam pelaksanaan yang dilakukan oleh Pemerintah Desa sampai dengan pengawasan yang diakhiri dengan permintaan pertanggungjawaban 
Kepala Desa sebagai pelaksana kegiatan yang ada di desa.

Pemerintah Desa Ketanggungan Kecamatan Dukuhturi Kabupaten Tegal, telah berhasil menyusun regulasi sesuai dengan ketentuan Peraturan Pemerintah Nomor 72 Tahun 2005, khususnya tentang Peraturan Desa yang mengatur Anggaran Pendapatan Dan Belanja Desa. Beberapa tatanan hukum lain yang telah ada yaitu:

1. Peraturan Desa Ketanggungan Nomor: 1 Tahun 2017 tentang : Susunan Organisasi Tata Kerja (STOK) Pemerintah Desa Ketanggungan;

2. Peraturan Desa Ketanggungan Nomor: 2 Tahun 2018 tentang : Rencana Kerja Pemerintahan Desa (RKP) Desa Tahun 2018 ;

3. Peraturan Desa Ketanggungan Nomor: 3 Tahun 2017 tentang : Anggaran Pendapatan dan Belanja Desa (APBDes) 2018, Susunan Organisasi Tata Kerja (STOK) Pemerintah Desa Ketanggungan;

4. Peraturan Desa Ketanggungan Nomor: 09 Tahun 2017 tentang : Pembentukan Kepengurusan Dan Pengelolaan Badan Usaha Milik Desa;

5. Peraturan Desa Ketanggungan Nomor: 05 Tahun 2017 tentang : Perubahan Anggaran Dan Belanja Desa (APBDes) Perubahan Tahun 2017;

6. Peraturan Desa Ketanggungan Nomor: 6 Tahun 2017 tentang : Sewa Asset Desa ;

7. Peraturan Desa Ketanggungan Nomor: 7 Tahun 2017 tentang : Tunjangan Bagi Kepala Desa Dan Aperat Desa; Kerja (STOK) Pemerintah Desa Ketanggungan;

8. Keputusan Kepala Desa Ketanggungan Nomor 15 Tahun 2015 tentang Pengukuhan Dan Pengangkatan Perangkat Desa Dalam Jabatan di lingkungan Pemerintah Desa Ketanggungan, Kecamatan Dukuhturi Kabupaten Tegal.

9. Keputusan Kepala Desa Ketanggungan Nomor 1 Thun 2017 tentang Pengukuhan Dan Pengangkatan Perangkat Desa Dalam Jabatan Sekretaris Desa Dan Kepala Seksi Di Pemerintah Desa Ketanggungan;

Alur proses legislasi PERDES sesuai dengan bagan legislasi disusun dalam satu kesatuan secara hierarkhis sesuai dengan peraturan perundang-undangan di Indonesia, yakni UUD Negara RI Tahun 1945 sebagai norma dasar dalam pembentukan Peraturan Desa, yang kemudian di implementasikan melalui Undang-Undang Nomor 32 Tahun 2004, Undang-Undang Nomor 12 Tahun 2008 tentang Otonomi Daerah, selanjutnya diatur lebih lanjut dengan Peraturan Pemerintah Nomor 72 Tahun 2005 tentang Desa, yang terkait dengan pembentukan dan mekanisme penyusunan Peraturan Desa (PERDES) diperjelas dan diatur dalam Peraturan Menteri Dalam Negeri Nomor 29 Tahun 2006 tentang Pedoman Pembentukan dan Mekanisme Penyusunan Peraturan Desa, sebagai ketentuan lebih lanjut diatur dalam Peraturan Daerah (PERDA).

Badan Permusyawaratan Desa (BPD) dan Pemerintah Desa kemudian merancang dan menyusun Peraturan Desa berdasarkan aspirasi dan kebutuhan masyarakat. Yang kemudian dituangkan dalam Peraturan Desa yang harus ditaati dan dilaksanakan oleh semua elemen Masyarakat Desa bersangkutan, karena hukum memiliki fungsi untuk mengatur kehidupan masyarakat dalam menjalankan aktivitasnya, sehingga melalui 
pengaturan itu bisa terwujud satu masyarakat yang sejahtera, sesuai dengan yang diamanatkan dari tujuan negara Indonesia yang tercantum dalam Pembukaan UUD Negara RI Tahun 1945. Pada titik tertentu hukum berfungsi sebagai sarana untuk memperlancar proses interaksi. Dalam konteks yang demikian itu, ide hukum sesungguhnya diperlukan untuk membangun kehidupan masyarakat yang demokratis, seperti halnya pembahasan APBDes yang transparan yang melibatkan masyarakat melalui Badan Permusyawaratan Desa (BPD).

Berdasarkan hasil penelitian diperoleh gambaran bahwa kerangka Peraturan Desa di Kecematan Dukuhturi khususnya di 4 (empat) desa yaitu Ketanggungan, Debong Wetan, Pengarasan dan Grogol telah memenuhi syarat dan telah sesuai dengan UndangUndang Nomor 10 tahun 2004 tentang Pembentukan Peraturan Perundang-undangan. Dan Permendagri No 29 Tahun 2006 Tentang Pedoman Pembentukan dan Mekanisme Penyusunan Peraturan Desa, akan tetapi masih ada beberpa kesalahan yang sering terjadi yaitu didalam konsideran terkait dengan dasar hukum, kebanyakan dari Pemerintah Desa masih banyak yang mengacu pada undang-undang yang lama.

Badan Perwakilan Desa (BPD) yang ada selama ini berubah namanya menjadi Badan Permusyawaratan Desa. BPD merupakan perwujudan dari demokrasi penyelenggaraan Pemerintahan Desa sebagai unsur penyelenggara Pemerintah Desa. Sedangkan keanggotaan BPD terdapat dalam Pasal 30 Peraturan Pemerintah Nomor 72 Tahun 2005 Jo Pasal 6 Ayat (3) Peraturan Daerah Kabupaten Tegal Nomor 14 Tahun 2016 Jo Pasal 7 Peraturan Bupati Tegal Nomor 14 Tahun 2016 tentang Perubahan atas Peraturan Daerah Kabupaten Tegal Kepala Desa, Perangkat Desa, dan Badan Permusyawaratan Desa, ialah terdiri dari wakil penduduk Desa bersangkutan yang ditetapkan dengan cara musyawarah dan Mufakat. Yang dimaksud dengan wakil masyarakat dalam hal ini seperti ketua Rukun warga, pemangku adat dan tokoh masyarakat. Masa jabatan BPD 6 (enam) tahun dan dapat dipilih kembali 1 kali masa jabatan berikutnya.

Mekanisme pembentukan penetapan calon anggota BPD dilakukan secara musyawarah mufakat, sesuai dengan pasal 62 Peraturan Daerah Kabupaten Tegal Nomor 6 tahun 2015 tentang Kepala Desa, Perangkat Desa, dan Badan Permusyawaratan Desa yaitu:

1. Calon Anggota BPD ditetapkan secara musyawarah dan mufakat

2. Mekanisme musyawarah dan mufakat adalah:

a. pemerintah desa memfasilitasi terselenggaranya musyawarah 
b. musyawarah dan mufakat dihadiri Ketua Rukun Warga, pemangku adat, golongan profesi, pemuka agama, tokoh perempuan dan toko atau pemuka masyarakat lainnya;

c. Ketua Rukun Warga, pemangku adat, golongan profesi, pemuka agama, toko perempuan dan toko atau pemuka masyarakat lainnya yang ada didesa dan memenuhi syarat dapat menjadi anggota BPD;

d. Musyawarah dan mufakat dilaksanakan untuk membentuk atau memilih sejumlah anggota BPD;

e. Hasil musyawarah mufakat sebagaimana dimaksud pada ayat 2 huruf b, c dan d dilaporkan kepada Kepala Desa untuk ditetapkan dengan Keputusan Bupati ;

f. Hasil musyawarah mufakat dicatat dan dituangkan dalam berita acara jalannya musyawarah, termasuk nama-nama peserta musyawarah yang terpilih menjadi anggota BPD dan dilampiri daftar hadir peserta musyawarah;

g. Dua bulan sebelum berakhirnya masa jabatan BPD, kepala Desa memberitahukan mengenahi akan berakhirnya masa jabatan BPD;

h. Pemerintah Desa memfasilitasi pembentukan anggota BPD yang baru;

i. Peserta musyawarah adalah ketua Rukun Warga< Pemaangku adat, Golongan Profesi, Pemuka Agama, toko perempuan dan toko aatau pemuka masyarakat lainnya;

j. Yang dapat dipilih menjadi calon anggota BPD adalah peserta musyawarah;

k. Jumlah anggota BPD ditetapkan dengann jumlah ganjil, paling sedikit 5 (lima) orang dan paling banyak 9 (Sembilan) orang, dengan memperhatikan luas wilayah, jumlah penduduk dan kemampuan keuangan desa serta disesuaikan dengan kebutuhan desa;

1. Jumlah anggota BPD ditentukan berdasarkan jumlah penduduk Desa yang bersangkutan, dengan ketentuan sebagai berikut ;

a. Jumlah penduduk sampai 5000 jiwa, 5 anggota;

b. Jumlah penduduk sampai 5001 jiwa sampai dengan 7000 jiwa, 7 anggota; dan

c. Jumlah penduduk sampai lebih dari 7000 jiwa, 9 anggota.

Temuan penelitian membuktikan bahwa ada beberapa kendala pelaksanaan peran BPD dalam proses penyusunan dan penetapan Peraturan Desa, apabila dicermati terdapat berbagai aturan kebiasaan desa yang berlaku dan sudah berjalan cukup lama tetapi belum diwujudkan dalam bentuk peraturan tertulis, hal ini dapat menjadi salah satu indikasi adanya beberapa kendala bagi BPD dalam menjalankan tugas dan wewenangnya dalam menjalankan fungsi legislasi. Adapun kendala pelaksanaan fungsi legislasi oleh BPD di Kecamatan Dukuhturi dapat dikemukakan sebagai berikut :

1. Kendala masih rendahnya sumber daya manusia di bidang hukum dari Anggota BPD. Hal ini menjadi persoalan disebabkan dalam pembentukan peraturan perundang-undangan meliputi kegiatan yang berhubungan dengan isi atau substansi peraturan, metoda pembentukan, serta proses dan prosedur pembentukan peraturan. Setiap bagian kegiatan tersebut harus memenuhi persyaratanpersyaratannya sendiri agar produk hukum tersebut dapat berlaku sebagaimana mestinya, baik secara yuridis, politis, maupun sosiologis.

Pada dasarnya Pemerintah Desa Ketanggungan selalu melakukan koordinasi untuk melakukan pembahasan akan tetapi masih mengalami kesulitan dalam mencari dasar hukum dan membuat aturan pidananya. Selain itu juga di Desa 
Grogol, koordinasi yang dilakukan antara BPD, Pemerintah Desa dan Tokoh Msyarakat Desa contoh ketika akan membahas Rancangan Peraturan Desa mengenai pembangunan Gedung PKK dan Serba Guna, rancangan peraturan tersebut hanya berbentuk kesepakatan tanpa ada realisasi untuk menuangkannya dalam bentuk Peraturan Desa tertulis.

2. Kurangnya Bimbingan Teknis dari Pemerintah Daerah khususnya dalam Bidang Legislasi, sehingga dalam pembuatan PERDES masih banyak yang salah bahkan cacat hukum, terutama didalam dasar hukum dalam konsideran masih banyak PERDES yang mengacu pada undang-undang lama.

3. Politik Kepentingan

Hukum tidak bisa terlepas dari subsitem kemasyarakatan lainnya, politik kerap melakukan intervensi atas pembuatan dan pelaksanaan hukum. Hubungan timbal balik dari politik dan hukum, hukumlah yang terpengaruh oleh politik, karena subsistem politik memiliki konsentrasi energi yang lebih besar daripada hukum.

Rendahnya sumberdaya manusia di bidang hukum dari anggota BPD belum ada pemecahan yang memadai. Namun demikian langkah-langkah untuk meningkatkan pengetahuan telah dilakukan melalui pertemuan-pertemuan antara perangkat desa, anggota BPD dan masyarakat, selain itu juga dilakukan dengan cara para anggota BPD dan Kepala Desa serta perangkatnya diberikan dasar pengetahuan tentang legal drafting melalui tutor ataupun pejabat kecamatan yang diundang langsung oleh Kepala Desa. Penyusunan produk hukum dalam hal ini Peraturan Desa sudah tentu terdapat norma-norma atau ketentuan yang harus dijadikan sebagai pedoman, namun demikian untuk dapat memahami suatu ketentuan Peraturan Perundang-undangan dengan baik, tepat dan benar, seringkali BPD mengalami kesulitan pemahaman, untuk itu mereka perlu mendapatkan dasar pengetahuan tentang legal drafting.

Rendahnya intensitas pembinaan, pendidikan dan pelatihan para anggota BPD dalam menyusun Peraturan Desa yang seharusnya dilakukan oleh pejabat Pemerintah Daerah, BPD menempuh langkah dengan mengadakan musyawarah dalam memecahkan berbagai permasalahan dalam pembentukan Peraturan Desa. Melalui musyawarah ternyata permasalahan dapat diselesaikan oleh semua pihak dengan baik. Hal ini juga mengandung makna seperti hasil pembinaan, karena hasil pembinaan dalam penyusunan Peraturan Desa tujuan akhirnya adalah untuk mewujudkan kondisi kehidupan warga desa yang lebih teratur, tertib aman dan damai.

Usaha peningkatan kesadaran hukum pada masyarakat, Pemerintah Desa selalu mensosialisasikan dan selalu mengajak untuk mengikutsertakan masyarakat dalam proses legislasi dalam hal politik kepentingan Pemerintah Desa selalu menghimbau untuk meminimalisir agar tidak terjadi peraturan yang tumpang tindih (overlap) atau tidak memihak rakyat. 
Berdasarkan kenyataan diatas, dapat ditarik kesimpulan bahwa langkah yang dilakukan BPD dalam hal pembentukan Peraturan Desa sudah cukup baik. Guna kelancaran fungsi legislasi BPD diperlukan adanya tenaga yang memfasilitasi sebagai fasilitator di bidang pelaksanaan fungsi legislasi BPD. Fasilitator ini membantu baik Pemerintah Desa maupun BPD dalam menjalankan tugas masing-masing khususnya pelaksanaan fungsi legislasi.

\section{PENUTUP}

\subsection{Simpulan}

Uraian pembahasan diatas dapatlah dikemukakan bahwa dapat diambil kesimpulan antara lain sebagaui berikut:

1. Peranan BPD (Badan Permusyawaratan Desa) dalam proses dan penyusunan Peraturan Desa (PERDES) berdasarkan Peraturan Pemerintah Nomor 72 Tahun 2005.

2. Fungsi dari Badan Permusyawaratan Desa ialah menetapkan Peraturan Desa bersama dengan Kepala Desa, menampung dan menyalurkan aspirasi masyarakat, oleh karena itu BPD sebagai Badan Permusyawaratan yang berasal dari masyarakat desa, disamping menjalankan fungsinya sebagai jembatan penghubung antara kepala desa dengan masyarakat desa, juga harus menjalankan fungsi utamanya yaitu fungsi representasi tugas dan wewenang dari Badan Permusyawaratan Desa.

3. Faktor kendala yang mempengaruhi fungsi legislasi BPD dalam proses penyusunan dan penetapan Peraturan Desa yaitu rendahnya sumberdaya manusia anggota BPD di bidang hukum dan kurangnya bimbingan teknis dari Pemerintah Daerah khususnya dalam bidang legislasi dan adanya politik kepentingan.Upaya yang dilakukan oleh Pemerintah Desa untuk mengatasi kendala melalui forum pertemuan rutin/ konsolidasi antar Perangkat Desa dengan BPD serta masyarakat, Kepala Desa mengundang tutor dari kecamatan untuk memberi pengetahuan tentang legal drafting, dan Pemerintah Desa selalu mensosialisaikan dan menghimbau kepada masyarakat untuk ikut aktif dalam pembuatan Perdes.

\subsection{Saran}

Perlu adanya perhatian khusus dari Pemerintah Daerah untuk dilakukan pelatihan tentang tata cara menyusun dan merancang Peraturan Desa bagi Pemerintah Desa dan Badan Permusyawaratan Desa, agar dapat menjadi produk hukum yang berlaku secara yuridis, politis, maupun sosiologis. Dalam pembahasan penyusunan serta penetapan Peraturan Desa agar aspirasi dan partisipasi masyarakat diperhatikan dan dilibatkan dalam pembahasan, sehingga produk hukum yang dihasilkan diterima dan mendapat pengakuan dari masyarakat serta pelaksananya berjalan efektif. Selanjutnya hal yang perlu dilakukan membentuk suatu wadah atau forum yang khusus mengawasi kinerja BPD dan Kepala 
Desa mengingat BPD dan Kepala Desa adalah unsur pemerintahan paling bawah dan mendasar dalam penyelenggaraan pemerintahan.

\section{DAFTAR PUSTAKA}

\section{A. Buku-Buku:}

Ali, Ahmad. (2002). Menguak Tabir Hukum (Suatu Kajian Sosiologis dan Filosofis). Jakarta: PT Toko Gunung Agung.

Kartohadikoesoema, Sutardjo. (1984). Desa. Bandung: Sumur Bandung.

Rahardjo, Satjipto. (2000). Ilmu Hukum. Bandung: Alumni.

Ridwan, Juniarso. - Sudrajat, Achmad Sodik. (2009). Hukum Administrasi Negara dan Kebijakan Pelayanan Publik. Bandung: Nuansa.

Sutrisno, Endang. (2009). Bunga Rampai Hukum dan Globalisasi. Yogyakarta: Genta Press.

Warassih, Esmi. (2005). Pranata Hukum Sebuah Telaah Sosiologi. Semarang: PT Suryandaru Utama.

Wasistiono, Sadu. - Tahir, M.Irawan. (2007). Prospek Pengembangan Desa. Bandung: CV Fokus Media.

\section{B. JURNAL NASIONAL \& JURNAL INTERNASIONAL}

Artadi, Ibnu. (2011). Dekonstruksi Pemahaman Penyelesaian Sengketa Bisnis (Ekonomi dan Keuangan) Beraspek Pidana melalui Prosedur Perdamaian: Menuju Proses Peradilan Pidana Rekonsiliatif. Jurnal Hukum Responsif Fakultas Hukum Universitas`Swadaya Gunung Jati Cirebon. 1. (1).33-34.

Atmasasmita, Romli. (2012).Tiga Paradigma Hukum dalam Pembangunan Nasional. Jurnal Hukum Prioris Fakultas Hukum Universitas Trisakti. 3 (1).5.

Bureni, Yunus. (2013). Moralitas Pembentukan Peraturan Daerah dalam Upaya Mencapai Keadilan Substantif (Morality Formation of Local Regulations in An Effort to Ensure Substantive Justice). Jurnal Legislasi Indonesia. 10 (20).125.

Dayanto. (2013).Rekonstruksi Paradigma Pembangunan Negara Hukum Indonesia Berbasis Pancasila. Jurnal Dinamika Hukum. 13 (3).498.

Hertogh, Marc. (2004). A European Conception of Legal Consciousness: Rediscovering Eugen Ehrlich. Journal of Law and Society. 31 (4).4. 
Kushandajani.(2008).Otonomi Desa Berbasis Modal Sosial Dalam Perspektif Socio Legal. FISIP UNDIP, Semarang.70-71.

Muhammad Irawan dkk. (2018). The Role of Judges in Realizing Justice: A Criminal Justice Perspective. Journal of Law, Policy and Globalization. International Institute for Science, Technology \& Education Accelerating Global Knowledge Creation and Sharing. 76.114.

Prentha, Bahria. (2011). Filsafat Hukum dan Nilai-Nilai Pancasila. Jurnal Ilmiah Kebijakan Hukum. Pusat Pengkajian dan Pengembangan Kebijakan Kementerian Hukum dan HAM RI. 5 (2).177.

Paserangi, Hasbir. (2016). Geographical Indications Protection "Pulut Mandoti Rice" as an Alternative of People Economic Empowerment. Journal of Law, Policy and Globalization. International Institute for Science, Technology \& Education Accelerating Global Knowledge Creation and Sharing.54.143.

Sutrisno, Endang. (2014). Implementasi Pengelolaan Sumberdaya Pesisir Berbasis Pengelolaan Wilayah Pesisir Secara Terpadu Untuk Kesejahteraan Nelayan. Jurnal Dinamika Hukum. 14 (1).3. . (2015). Tracing the Performance of Law in Indonesia (A Perspective of Thomas Kuhn's "Normal Science", Journal of Law, Policy and Globalization. International Institute for Science, Technology \& Education Accelerating Global Knowledge Creation and Sharing. 37.126.

Sutrisno, Endang-Sudarminto. (2017). Legal Culture of Fisherman Communities in Indonesia (Studies in Cirebon Coastal Fishing Communities in the Northern Coast of West Java, Indonesia. International Journal of Current Advanced Research. 6 (2).2249-2253.

Yasin, Rahman. (2014). Telaah Putusan MK dalam Sengketa PHPU Pilpres 2004 (Perspektif Negara Demokrasi Konstitusional). Jurnal Konstitusi. 11 (4).652. 